\title{
Optimasi Biaya Pengadaan dan Persediaan Sapi pada RPH Z Menggunakan Metode Economic Order Quantity (EOQ)
}

\author{
Linda Lestari $^{1 *}$, Maulida Boru Butar Butar ${ }^{2}$ \\ 1,2 Teknik Industri, Universitas Gunadarma, Depok, Indonesia \\ ('lindhalestari04@gmail.com)
}

\begin{abstract}
Abstrak - Rumah Pemotongan Hewan (RPH) Z merupakan RPH yang berada di Kota Bekasi dengan tugas membantu pemerintahan Kota Bekasi dalam memenuhi kebutuhan daging sapi masyarakat Kota Bekasi. Disediakan dua jenis sapi untuk pemenuhan kebutuhan daging sapi yaitu sapi impor dan sapi lokal. Permasalahan yang terjadi adalah saat ini di RPH Z belum memiliki perencanaan pengadaan dan pengendalian persediaan sapi yang mengakibatkan biaya pengadaan dan biaya persediaan tinggi. Dibutuhkan adanya perencanaan pengadaan dan persediaan sapi pada RPH $Z$ agar biaya pengadaan dan persediaan dapat diminimasi tanpa mengganggu pemenuhan permintaan daging sapi. Makalah ini akan melakukan peramalan permintaan terlebih dahulu dengan menggunakan metode Triple Exponential Smoothing karena data permintaan daging sapi termasuk data musiman dan trend. Hasil peramalan digunakan untuk optimasi biaya pengadaan dan persedian sapi di RPH dengan menggunakan metode Economic Order Quantity (EOQ), kemudian hasil dari penggunaan metode EOQ akan dibandingkan penghematannya dengan biaya pengadaan dan persediaan berdasarkan kondisi aktual di RPH.
\end{abstract}

Kata kunci: Economic Order Quantity (EOQ); peramalan; persediaan

\section{PENDAHULUAN}

Salah satu hasil peternakan di Indonesia yang menjadi andalan sebagai sumber nutrisi berkualitas bagi manusia adalah daging sapi. Daging sapi dikenal sebagai sumber protein yang penting sebagai penunjang dalam pemenuhan kebutuhan dasar bahan pangan. Tingginya permintaan daging sapi nasional yang harus dipenuhi oleh pemerintah menunjukkan bahwa masyarakat Indonesia menjadikan daging sapi sebagai salah satu sumber utama pemenuhan kebutuhan protein hewani. Maka salah satu usaha untuk pemenuhan kebutuhan daging sapi sebagai bahan pangan, Dinas Ketahanan Pangan Pertanian dan Perikanan berupaya mendirikan Rumah Pemotongan Hewan (RPH) yang berperan penting sebagai mata rantai untuk memperoleh daging sapi dengan kualitas yang baik.

RPH Z terletak di Kota Bekasi yang membantu pemerintahan Kota Bekasi dalam memenuhi permintaan daging sapi di Kota Bekasi. Peran RPH Z adalah melaksanakan kegiatan teknis operasional dan/atau kegiatan teknis penunjang Dinas Ketahanan Pangan Pertanian dan Perikanan di Kota Bekasi.

Kota Bekasi merupakan salah satu wilayah dengan jumlah permintaan daging sapi terbanyak. Berdasarkan artikel yang dimuat pada harian Republika pada tanggal 20 Januari 2021, kebutuhan daging sapi di Kota Bekasi semakin meningkat setiap harinya dan akan mengalami lonjakan permintaan di hari tertentu seperti hari raya dan hari libur nasional. Banyaknya permintaan daging sapi tersebut membuat RPH Z berusaha untuk memenuhi seluruh permintaan dengan cara mengadakan persediaan sapi impor dan sapi lokal dalam jumlah banyak berdasarkan pengalaman pribadi dari kepala RPH tanpa melakukan perencanaan jumlah sapi yang dipesan dan jumlah pemesanan yang harus dilakukan. Saat ini, diketahui harga sapi impor sebesar Rp22.770.000/ekor dan harga sapi lokal sebesar Rp19.480.000/ekor dengan biaya pakan sapi setiap harinya mencapai Rp27.000/ekor. Harga sapi dan biaya pakan tersebut menjadi faktor-faktor yang mengakibatkan tingginya biaya pengadaan dan persediaan yang harus dikeluarkan oleh RPH Z.

Berdasarkan permasalahan yang dialami oleh RPH Z, maka perlu dilakukan penentuan kuantitas pengadaan dan persediaan sapi yang tepat sehingga total biaya yang dikeluarkan RPH menjadi optimal dalam memenuhi permintaan.

Pada makalah kali ini penentuan kuantitas pengadaan dan persediaan sapi, langkah pertama adalah melakukan peramalan untuk permintaan daging sapi di masa yang akan datang dengan menggunakan metode Triple Exponential Smoothing, kemudian hasil peramalan digunakan untuk menentukan jumlah dan periode pengadaan sapi agar mendapatkan total biaya pengadaan dan persediaan sapi yang optimal dengan menggunakan metode Economic Order Quantity (EOQ). 


\section{STUDI LITERATUR}

\section{A. Peramalan}

Peramalan didefinisikan sebagai kegiatan yang dilakukan untuk memperkirakan apa yang terjadi pada periode waktu yang akan datang. Peramalan merupakan alat untuk membantu para pembuat kebijakan memahami risiko dari ketidakpastian di masa yang akan datang, sehingga dapat membantu mengidentifikasi risiko dan membantu pembuat kebijakan dalam proses pengambilan keputusan (Raihan, 2020).

\section{B. Pola Data}

Pola data permintaan menjadi dasar pemilihan deret waktu berkala yang nantinya diperlukan untuk memilih metode peramalan yang sesuai. Beberapa jenis pola data adalah sebagai berikut (Widjajati, Soehardjoepri, \& Fani, 2017):

1. Pola horizontal $(\mathrm{H})$, terjadi jika data yang ada berfluktuasi di sekitar nilai rata-rata yang konstan.

2. Pola musiman (S), terjadi jika data dipengaruhi oleh faktor musiman (kuartal tahun, bulanan atau hari-hari pada minggu tertentu).

3. Pola trend (T), terjadi jika terdapat kenaikan atau penurunan pada jangka panjang dalam data.

4. Pola siklis (C), terjadi jika data dipengaruhi oleh fluktuasi ekonomi jangka panjang seperti yang berhubungan dengan siklus bisnis.

\section{Metode Peramalan}

Metode peramalan yang akurat adalah pemilihan metode sesuai dengan pola data historis permintaan. Berdasarkan jenis pola data yang telah disebutkan sebelumnya (pada bagian B), metode peramalan yang sesuai adalah sebagai berikut (Lusiana, 2020) :

1. Metode peramalan data stasioner: simple averaging, moving average, dan autoregressive moving average

2. Metode peramalan data trend: holt linear exponential smoothing, simple regression, dan ARIMA.

3. Metode peramalan data musiman: decomposition, triple exponential smoothing, multiple regression, dan autoregressive integrated moving average (ARIMA)

4. Metode peramalan data siklis: decomposition, econometric models, multiple regression, dan ARIMA.

\section{Triple Exponential Smoothing (Winter's Method)}

Berdasarkan pengamatan kebutuhan daging sapi, diperkirakan bahwa pola data permintaan daging sapi adalah data musiman sehingga penjelasan metode pemulusan triple exponential smoothing ditambahkan pada makalah ini. Metode ini sering disebut sebagai metode Winter's yang digunakan jika data permintaan memiliki pola data musiman. Metode triple exponential smoothing didasarkan pada tiga persamaan pemulusan, yaitu persamaan pemulusan keseluruhan, pemulusan trend, dan pemulusan musiman (Fani, 2017).

\section{E. Pengadaan}

Pengadaan merupakan aktivitas yang dilakukan oleh perusahaan untuk menjamin ketersediaan bahan baku yang digunakan pada proses produksi sehingga dapat diolah menjadi suatu barang jadi. Pengadaan berhubungan dengan pemasok sehingga perusahaan dapat memilih bahan baku yang tepat (Giharni, 2012).

\section{F. Persediaan}

Persediaan merupakan barang yang disimpan dengan tujuan untuk diproduksi atau dijual kembali pada waktu tertentu. Persediaan timbul karena produk tidak digunakan pada saat itu, tetapi akan digunakan pada waktu yang akan datang (Amalia, 2017).

Biaya Persediaan umumnya terdiri dari beberapa biaya yang mempengaruhi total biaya. Biaya tersebut adalah biaya pembelian (purchasing cost), biaya pemesanan (order cost/setup cost), biaya penyimpanan (holding cost), dan biaya kekurangan (stockout cost/depletion cost) (Ginting, 2017). 


\section{G. Economic Order Quantity (EOQ)}

$E O Q$ adalah analisis yang digunakan untuk menentukan jumlah pembelian bahan baku yang paling ekonomis untuk mencapai tingkat persediaan yang minimal, biaya rendah, dan mutu yang baik. Selain itu, penerapan metode EOQ membantu perusahaan untuk mengurangi biaya penyimpanan, penghematan ruang untuk gudang, dan kerusakan bahan baku karena penyimpanan dalam waktu yang lama (Andira, 2017).

Pemesanan menggunakan metode EOQ memiliki jumlah produk yang sama atau konstan, tetapi waktu pemesanan bahan baku tidak akan sama dalam satu tahun. EOQ dapat dihitung dengan menggunakan rumus sebagai berikut (Ardiansyah, 2018):

$$
\mathrm{EOQ}=\sqrt{\frac{2 \mathrm{D} \mathrm{S}}{\mathrm{H}}}
$$

Keterangan :

$\mathrm{D}=$ Jumlah penggunaan bahan baku dalam 1 tahun

$\mathrm{S}=$ Biaya pemesanan setiap sekali pesan

$\mathrm{H}=$ Biaya penyimpanan per kilogram

Berdasarkan ukuran pemesanan EOQ di atas, maka dapat ditentukan frekuensi pemesanan dalam setahun. Rumus yang digunakan untuk menghitung frekuensi pemesanan adalah sebagai berikut (Ardiansyah, 2018):

$$
\mathrm{F}=\frac{\mathrm{D}}{\mathrm{Q}}
$$

Keterangan :

$\mathrm{F}=$ Frekuensi pemesanan dalam setahun

$\mathrm{Q}=$ Kuantitas pembelian optimal

$\mathrm{D}$ = Jumlah penggunaan bahan baku dalam 1 tahun

Total annual cost (TAC) atau biaya total adalah jumlah dari total carrying cost (TCC) atau biaya penyimpanan dan total ordering cost (TOC) atau biaya pemesanan. Persamaan yang digunakan untuk menghitung total annual cost adalah sebagai berikut (Warella et al., 2021):

$$
\mathrm{TAC}=\mathrm{PD}+\frac{\mathrm{D}}{\mathrm{Q}} \mathrm{S}+\frac{\mathrm{Q}}{2} \mathrm{H}
$$

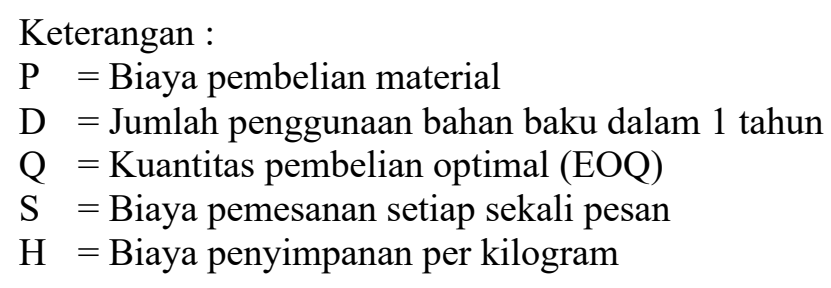

\section{METODOLOGI}

Pada makalah ini penulis membuat langkah-langkah yang dilakukan guna mendapatkan biaya pengadaan dan persediaan sapi yang optimal. Langkah-langkah tersebut dituangkan dalam diagram alir penelitian yang dapat dilihat pada Gambar 1. 


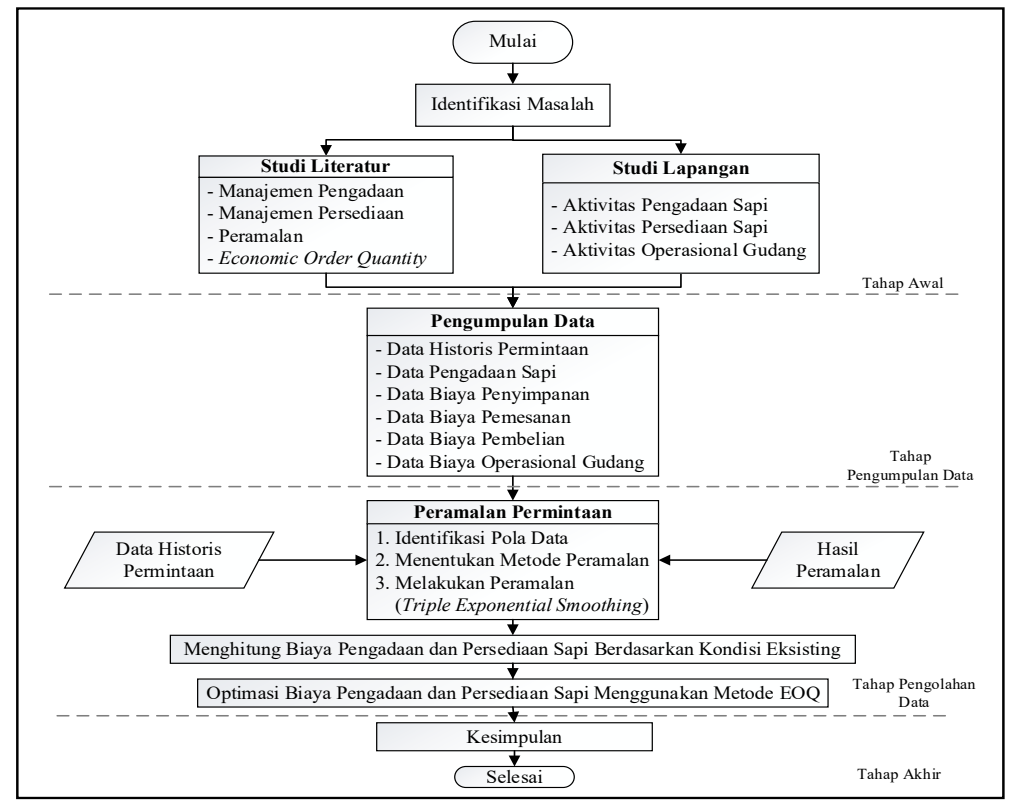

Gambar 1. Metodologi

Setelah masalah pada RPH Z teridentifikasi, maka eksplorasi literatur dilakukan bersama dengan pengamatan di lapangan agar seluruh data yang diperlukan dapat diperoleh. Setelah data didapatkan, maka dimulailah langkah optimasi biaya pengadaan dan persediaan sapi pada RPH Z. Berdasarkan pola data permintaan sebelumnya, peramalan permintaan sapi di masa yang akan datang dibuat. Dari peramalan permintaan yang ada dapat diketahui berapa kebutuhan sapi yang harus dipenuhi oleh RPH Z sehingga perhitungan total biaya pengadaan dan persediaan sapi dengan metode EOQ dilakukan. Analisa dari hasil dilakukan dengan membandingkan total biaya yang diperoleh menggunakan metode EOQ dengan biaya yang sebelumnya dikeluarkan oleh RPH Z. Di akhir makalah akan diambil kesimpulan berupa usulan bagi RPH Z.

\section{HASIL DAN DISKUSI}

\section{A. Peramalan Permintaan}

Peramalan permintaan dilakukan dengan tahapan pertama yaitu melakukan pengecekan data historis untuk mengetahui jenis pola data permintaan dengan menggunakan time series plot. Grafik pola data historis pemotongan sapi impor dan sapi lokal adalah sebagai berikut.

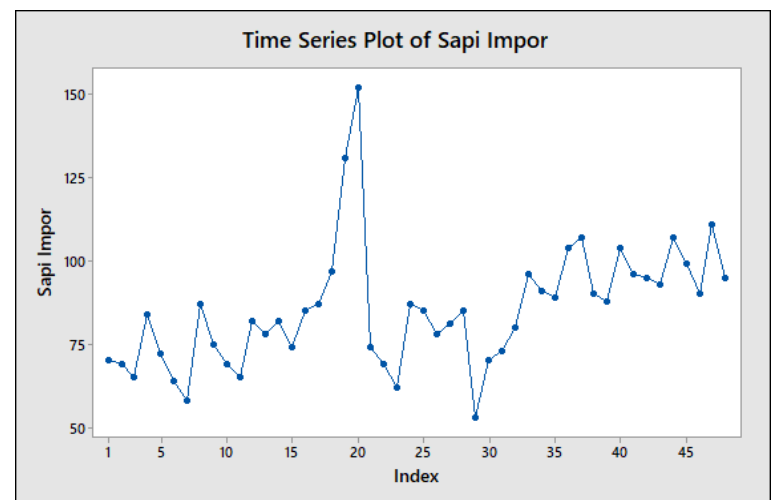

Gambar 2(a). Pola data sapi impor

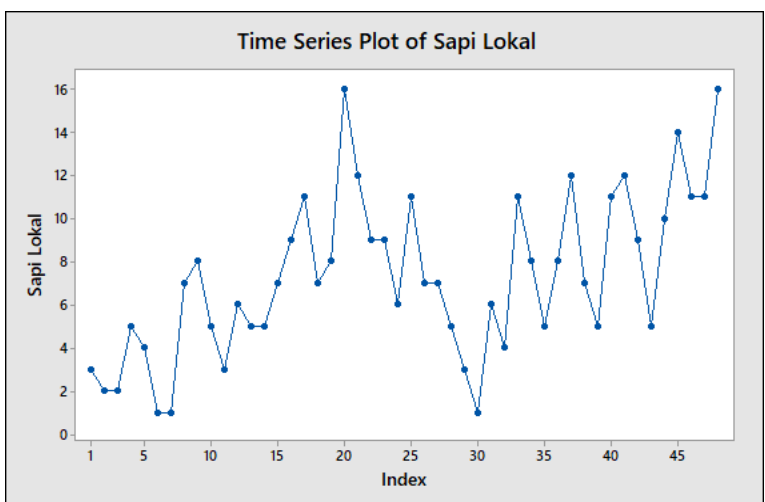

Gambar 2(b). Pola data sapi lokal

Berdasarkan gambar di atas, dapat diketahui bahwa pola data historis permintaan sapi impor dan sapi lokal tersebut bersifat fluktuatif serta termasuk data seasonal dan trend sehingga metode peramalan yang tepat adalah menggunakan metode Triple Exponential Smoothing. Peramalan dengan metode Triple Exponential 
Smoothing menggunakan 3 parameter pemulusan dengan memilih nilai $\alpha, \beta$, dan $\gamma$ yang menghasilkan nilai MAPE minimum. Penentuan bobot parameter pemulusan dilakukan dengan trial and error untuk kombinasi dari ketiga parameter tersebut dan dibandingkan nilai MAPE.

Berdasarkan hasil trial and error yang dilakukan, terdapat kombinasi terpilih dengan nilai MAPE yang lebih kecil dibandingkan dengan kombinasi yang lain. Berikut ini merupakan grafik peramalan permintaan menggunakan Winter's Method berdasarkan kombinasi parameter pemulusan yang terpilih.

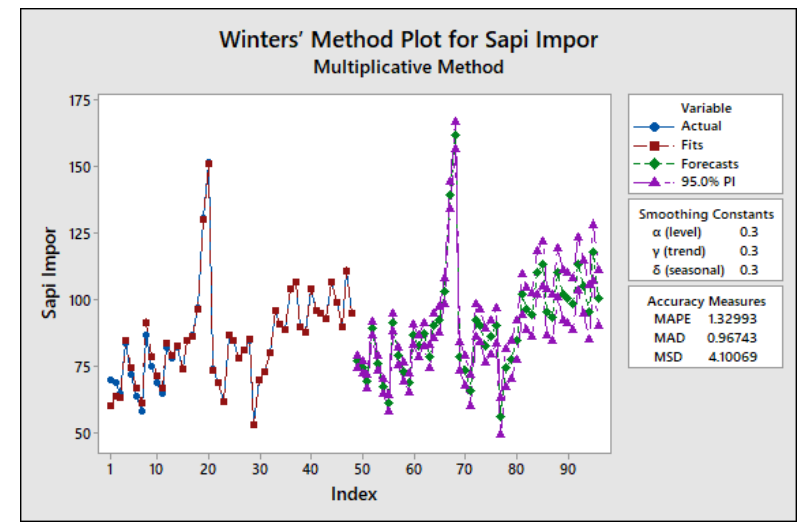

Gambar 3(a). Grafik Winter's Method sapi impor

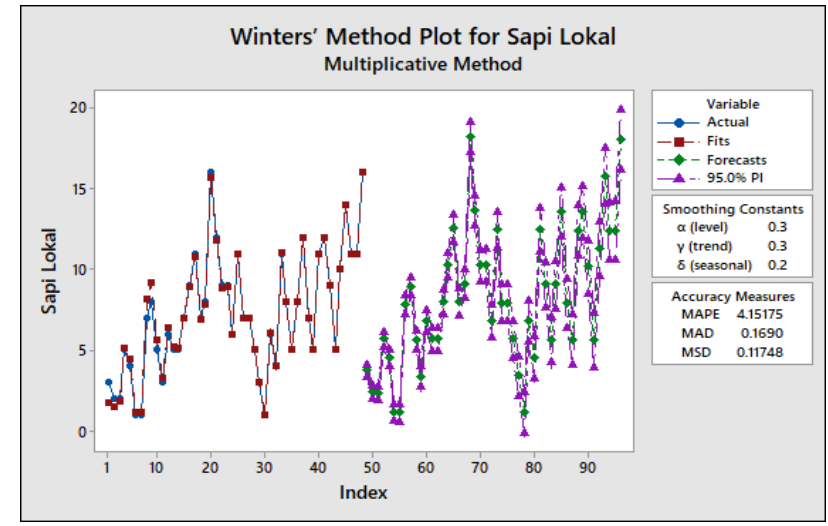

Gambar 3(b). Grafik Winter's Method sapi lokal

Kombinasi parameter pemulusan untuk peramalan permintaan jenis sapi impor adalah $\alpha=0.3, \beta=0.3$, dan $\gamma=0.3$ dengan nilai MAPE sebesar $6,84 \%$ sedangkan peramalan permintaan jenis sapi lokal adalah $\alpha=0.3, \beta$ $=0.3$, dan $\gamma=0.2$ dengan nilai MAPE sebesar $26,10 \%$. Hasil peramalan yang digunakan adalah hasil peramalan menggunakan parameter pemulusan tersebut yaitu sebagai berikut.

Tabel 1

Hasil peramalan

\begin{tabular}{|c|c|c|c|c|c|}
\hline \multirow{2}{*}{$\begin{array}{l}\text { Periode } \\
\text { (Minggu) }\end{array}$} & \multicolumn{2}{|c|}{ Jumlah Sapi } & \multirow{2}{*}{$\begin{array}{l}\text { Periode } \\
\text { (Minggu) }\end{array}$} & \multicolumn{2}{|c|}{ Jumlah Sapi } \\
\hline & Impor & Lokal & & Impor & Lokal \\
\hline 1 & 77 & 4 & 25 & 91 & 13 \\
\hline 2 & 75 & 3 & 26 & 83 & 8 \\
\hline 3 & 70 & 3 & 27 & 87 & 8 \\
\hline 4 & 90 & 6 & 28 & 91 & 6 \\
\hline 5 & 77 & 5 & 29 & 57 & 4 \\
\hline 6 & 68 & 2 & 30 & 75 & 2 \\
\hline 7 & 62 & 2 & 31 & 78 & 7 \\
\hline 8 & 92 & 8 & 32 & 86 & 5 \\
\hline 9 & 80 & 9 & 33 & 102 & 13 \\
\hline 10 & 73 & 6 & 34 & 97 & 10 \\
\hline 11 & 69 & 4 & 35 & 95 & 6 \\
\hline 12 & 87 & 7 & 36 & 111 & 10 \\
\hline 13 & 83 & 6 & 37 & 114 & 14 \\
\hline 14 & 88 & 6 & 38 & 96 & 8 \\
\hline 15 & 79 & 8 & 39 & 94 & 6 \\
\hline 16 & 91 & 11 & 40 & 111 & 13 \\
\hline 17 & 93 & 13 & 41 & 102 & 14 \\
\hline 18 & 104 & 8 & 42 & 101 & 11 \\
\hline 19 & 140 & 10 & 43 & 99 & 6 \\
\hline 20 & 162 & 19 & 44 & 114 & 12 \\
\hline 21 & 79 & 14 & 45 & 106 & 16 \\
\hline 22 & 74 & 11 & 46 & 96 & 13 \\
\hline 23 & 66 & 11 & 47 & 118 & 13 \\
\hline 24 & 93 & 7 & 48 & 101 & 19 \\
\hline \multicolumn{4}{|c|}{ Jumlah } & 4377 & 420 \\
\hline
\end{tabular}




\section{B. Total Biaya Berdasarkan Kondisi Eksisting}

Pada saat ini RPH Z memesan sapi impor pada pemasok dua kali seminggu dan sapi lokal satu kali seminggu dalam jumlah banyak untuk memenuhi kebutuhan daging sapi masyarakat Kota Bekasi. Berdasarkan kondisi tersebut, maka dapat diketahui total biaya yang harus dikeluarkan oleh RPH dengan komponen biaya sebagai berikut.

Tabel 2

Biaya pembelian

\begin{tabular}{lcc}
\hline \multicolumn{1}{c}{ Komponen } & Sapi Impor & Sapi Lokal \\
\hline Berat rata-rata sapi (kg) & $550 \mathrm{~kg}$ & $400 \mathrm{~kg}$ \\
Harga Sapi/ekor & $\mathrm{Rp} 22.770 .000$ & $\mathrm{Rp} 19.480 .000$ \\
\hline
\end{tabular}

Biaya pemesanan sapi yang harus dikeluarkan oleh RPH Teluk Pucung untuk setiap pemesanan sapi impor dan sapi lokal adalah sebagai berikut.

Tabel 3

Biaya pemesanan

\begin{tabular}{cl}
\hline Komponen Biaya & \multicolumn{1}{c}{ Biaya } \\
\hline Administrasi & Rp 20.000 \\
Komunikasi & $R p 15.000$ \\
Transportasi & Rp 1.650 .000 \\
Pemeriksaan & Rp 170.000 \\
\hline Total Biaya & Rp 1.855.000 \\
\hline
\end{tabular}

Biaya penyimpanan dihitung untuk setiap ekor sapi yang dipelihara. Biaya penyimpanan untuk setiap ekor sapi impor di RPH Z adalah sebagai berikut.

Tabel 4

Biaya penyimpanan sapi impor setiap ekor

\begin{tabular}{ccll}
\hline Komponen Biaya & Kebutuhan/hari (kg) & Biaya (/kg) & Biaya/hari \\
\hline Jerami Padi & 5 & Rp700 & Rp3.500 \\
Dedak Padi Halus & 5 & Rp2.000 & Rp10.000 \\
bungkil kelapa & 4 & Rp1.700 & Rp6.800 \\
Ampas Tahu & 3 & Rp1.500 & Rp4.500 \\
Vitamin & 1 & Rp2.000 & Rp2.000 \\
\hline & Total Biaya & & Rp26.800 \\
\hline
\end{tabular}

Sapi lokal memiliki jenis pakan yang sama dengan sapi impor tetapi dalam jumlah yang berbeda. Biaya penyimpanan untuk setiap ekor sapi lokal di RPH Z adalah sebagai berikut.

Tabel 5

Biaya penyimpanan sapi lokal setiap ekor

\begin{tabular}{ccll}
\hline Komponen Biaya & Kebutuhan/hari (kg) & Biaya (/kg) & Biaya/hari \\
\hline Jerami Padi & 3 & Rp700 & Rp2.100 \\
Dedak Padi Halus & 4 & Rp2.000 & Rp8.000 \\
bungkil kelapa & 3 & Rp1.700 & Rp5.100 \\
Ampas Tahu & 2 & Rp1.500 & Rp3.000 \\
Vitamin & 1 & Rp2.000 & Rp2.000 \\
\hline & Total Biaya & & Rp20.200 \\
\hline
\end{tabular}

Berdasarkan biaya pembelian, biaya pemesanan, dan biaya penyimpanan diatas maka dapat diketahui total biaya pengadaan dan persediaan sapi yang harus dikeluarkan oleh RPH Z. Berikut ini adalah perhitungan total biaya berdasarkan kondisi ekstisting RPH Z. 
Tabel 6.

Total biaya eksisting

\begin{tabular}{ll}
\hline \multicolumn{1}{c}{ Komponen Biaya } & \multicolumn{1}{c}{ Biaya } \\
\hline Biaya Pembelian & Rp 107.222.010.000 \\
Biaya Pemesanan & Rp 267.120.000 \\
Biaya Penyimpanan & Rp 440.260.800 \\
Biaya Operasional Gudang & Rp 49.486.598 \\
\hline Total Biaya & Rp 107.978.877.398 \\
\hline
\end{tabular}

\section{Optimasi Biaya Pengadaan dan Persediaan}

Optimasi pengadaan sapi dilakukan menggunakan metode Economic Order Quantity dengan tujuan untuk menentukan kuantitas pengadaan sapi sehingga total biaya yang harus dikeluarkan oleh RPH Z menjadi optimal. Perhitungan pengadaan sapi impor dan sapi lokal di RPH Z dengan menggunakan metode EOQ adalah sebagai berikut.

$$
\begin{aligned}
\text { EOQ Sapi Impor } & =\sqrt{\frac{2 \mathrm{D} \mathrm{S}}{\mathrm{H}}} & \text { EOQ Sapi Lokal } & =\sqrt{\frac{2 \mathrm{D} \mathrm{S}}{\mathrm{H}}} \\
& =\sqrt{\frac{2 \times 4110 \times 1.855 .000}{9.004 .800}} & & =\sqrt{\frac{2 \times 368 \times 1.855 .000}{6.787 .200}} \\
& =41,15 \approx 42 \mathrm{ekor} & & =14.183 \approx 15 \mathrm{ekor}
\end{aligned}
$$

Setelah melakukan perhitungan di atas, selanjutnya adalah menentukan frekuensi pemesanan sapi impor dan sapi lokal dalam satu tahun yaitu sebagai berikut.

$$
\begin{aligned}
\text { F Sapi Impor } & =\frac{\mathrm{D}}{\mathrm{Q}} & \text { F Sapi Lokal } & =\frac{\mathrm{D}}{\mathrm{Q}} \\
& =\frac{4110}{42}=97,857 \approx 98 \mathrm{kali} & & =\frac{368}{15}=24,533 \approx 25 \mathrm{kali}
\end{aligned}
$$

Selanjutnya dapat dilakukan perhitungan biaya yang harus dikeluarkan oleh RPH untuk biaya pengadaan dan persediaan sapi impor dan lokal selama satu tahun. Perhitungan total biaya di RPH Z menggunakan metode EOQ adalah sebagai berikut.

$$
\begin{aligned}
\text { TAC Sapi Impor } & =\mathrm{PD}+\frac{\mathrm{D}}{\mathrm{Q}} \mathrm{S}+\frac{\mathrm{Q}}{2} \mathrm{H} \\
& =(4110 \times 22.770 .000)+\left(\frac{4110}{42} \times 1.855 .000\right)+\left(\frac{42}{2} \times 9.004 .800\right) \\
& =93.584 .700 .000+181.790 .000+189.100 .800 \\
& =\operatorname{Rp} 93.955 .590 .800 \\
\text { TAC Sapi Lokal } & =\mathrm{PD}+\frac{\mathrm{D}}{\mathrm{Q}}+\frac{\mathrm{Q}}{2} \mathrm{H} \\
& =(368 \times 19.480 .000)+\left(\frac{386}{15} \times 1.855 .000\right)+\left(\frac{15}{2} \times 6.787 .200\right) \\
& =7.168 .640 .000+46.375 .000+50.904 .000 \\
& =\operatorname{Rp} 7.265 .919 .000
\end{aligned}
$$

Setelah dilakukan perhitungan menggunakan metode EOQ seperti diatas, maka dapat diketahui total biaya yang harus dikeluarkan oleh RPH. Biaya-biaya yang didapatkan dari perhitungan EOQ optimasi pengadaan dan persediaan sapi adalah sebagai berikut.

Tabel 7

Total biaya optimasi

\begin{tabular}{ll}
\hline \multicolumn{1}{c}{ Komponen Biaya } & \multicolumn{1}{c}{ Biaya } \\
\hline Biaya Pembelian & Rp 100.753.340.000 \\
Biaya Pemesanan & Rp 228.165.000 \\
Biaya Penyimpanan & Rp 240.004.800 \\
Biaya Operasional Gudang & Rp 49.486.598 \\
\hline Total Biaya & Rp 101.270.996.398 \\
\hline
\end{tabular}




\section{Perbandingan Kondisi Eksisting dengan Hasil Optimasi}

Perbandingan dilakukan untuk mengetahui penghematan yang dapat dilakukan. Berikut merupakan tabel perbandingan total biaya kondisi eksisting dengan total biaya hasil optimasi menggunakan metode EOQ.

Tabel 8

Perbandingan Total Biaya

\begin{tabular}{|c|c|c|c|c|}
\hline \multicolumn{2}{|c|}{ Komponen Biaya } & Eksisting & Hasil Optimasi & Penghematan \\
\hline \multirow{2}{*}{ Frekuensi Pesan } & Impor & 96 kali & 98 kali & - \\
\hline & Lokal & 48 kali & 25 kali & - \\
\hline \multicolumn{2}{|l|}{ Biaya Pembelian } & Rp 107.222.010.000 & Rp 100.753.340.000 & Rp6.468.670.000 \\
\hline \multicolumn{2}{|c|}{ Biaya Pemesanan } & $\operatorname{Rp} 267.120 .000$ & $\operatorname{Rp} 228.165 .000$ & Rp38.955.000 \\
\hline \multicolumn{2}{|c|}{ Biaya Penyimpanan } & $\mathrm{Rp} 440.260 .800$ & $\mathrm{Rp} 240.004 .800$ & Rp200.256.000 \\
\hline \multicolumn{2}{|c|}{ Biaya Operasional Gudang } & Rp 49.486 .598 & Rp 49.486 .598 & Rp0 \\
\hline \multicolumn{2}{|c|}{ Total } & Rp 107.978.877.398 & Rp 101.270.996.398 & Rp6.707.881.000 \\
\hline
\end{tabular}

Berdasarkan tabel perbandingan di atas, diketahui bahwa total biaya pengadaan dan persediaan sapi berdasarkan kondisi eksisting RPH Z sebesar Rp107.978.877.398, sedangkan total biaya pengadaan dan persediaan sapi hasil optimasi dengan menggunakan metode Economic Order Quantity sebesar Rp101.270.996.398 sehingga RPH dapat menghemat biaya sebesar 6,21\% yaitu Rp6.707.881.000. Penghematan tersebut dapat dialokasikan untuk pengembangan RPH Z.

\section{KESIMPULAN}

Kuantitas pengadaan sapi impor sebanyak 42 ekor sedangkan sapi lokal sebanyak 15 ekor setiap pemesanan dengan frekuensi pemesanan sapi impor sebanyak 98 kali dan sapi lokal 25 kali dalam setahun. Total biaya pengadaan dan persediaan sapi berdasarkan kondisi eksisting adalah Rp107.978.877.398 sedangkan total biaya hasil optimasi menggunakan metode EOQ sebesar Rp101.270.996.398 sehingga RPH dapat melakukan penghematan sebesar 6,21\% yaitu Rp6.707.881.000. Dari hasil ini dapat menjadi pertimbangan oleh RPH Z untuk dapat mengoptimalkan biaya.

\section{DAFTAR PUSTAKA}

Amalia, A. R. (2017). Optimasi Penentuan Tingkat Pengadaan Beras Pada Studi Kasus PT X. Institut Teknologi Sepuluh Nopember,

Andira, O. E. (2017). Analisis Persediaan Bahan Baku Tepung Terigu Menggunakan Metode EOQ (Economic Order Quantity) Pada Roti Puncak Makassar. Jurnal Ilmiah Ekonomi Bisnis, 21(3).

Ardiansyah, N. (2018). Analisa EOQ dan SS Pada Industri Spare Part Khususnya Anoda dengan Simulasi Monte Carlo. Institut Teknologi Sepuluh Nopember,

Fani, E. (2017). Perbandingan Metode Winter Eksponensial Smoothing dan Metode Event Based Untuk Menentukan Penjualan Produk Terbaik di Perusahaan X. Institut Teknologi Sepuluh Nopember,

Giharni. (2012). Prosedur Pengadaan Bahan Baku Produksi di PT Kusumahadi Santosa Jaten, Karanganyar. Universitas Sebelas Maret,

Ginting, Rosnani. (2017). Sistem Produksi. Yogyakarta: Graha Ilmu.

Lusiana, Anna. (2020). Penerapan Metode Peramalan (Forecasting) pada Permintaan Atap di PT X. Universitas Mercu Buana,

Raihan, M. (2020). Analisis Forecasting Produksi dan Kebutuhan Konsumsi Beras di Provinsi Sumatera Utara.

Warella, S. Y., Hasibuan, A., Yudha, H. S., Sisca, S., Mardia, M., Kuswandi, S., Prasetio, A. (2021). Manajemen Rantai Pasok. Yayasan Kita Menulis.

Widjajati, F. A., Soehardjoepri, S., \& Fani, E. (2017). Menentukan Penjualan Produk Terbaik di Perusahaan X Dengan Metode Winter Eksponensial Smoothing dan Metode Event Based. Journal of Mathematics Its Applications, 14(1), 25-35. 